\title{
SETTING JARINGAN MIKROTIK DAN PEMBUATAN CHANNEL YOUTUBE UNTUK MASJID JAMI' MANARUL HUDA SUMBERSARI KOTA MALANG
}

\author{
Mohamad As'ad ${ }^{1}$, Nasrul Firdaus ${ }^{2}$, Ali Syaifullah ${ }^{3}$ \\ ${ }^{1}$ Program Studi Teknologi Informasi, ${ }^{2,3}$ Program Studi Sistem Informasi, Fakultas Teknik \\ STMIK PPKIA Pradnya Paramita Malang \\ Email: asad@stimata.ac.id
}

\begin{abstract}
Information technology is one of the tools in various fields, including in the field of Islamic da'wah. Islamic da'wah with information technology in the form of live streaming recitation to youtube (online da'wah) is viral now. This online da'wah was the wish of Takmir and the congregation of Ma sjid Jami' Manarul Huda. Setting up the intemet network with Mikrotik and making channels on youtube at the Masjid Jami' Manarul Huda was community empowerment, namely the application of science and technology to the communityat the Masjid Jami'ManarulHuda. This program was a form of community service from STMIK PPKIA Pradnya Paramita (STIMATA) Malang. This community service aims to apply the knowledge that was on campus to the wider community, especially the MasjidJami 'Mana rul Huda so that they can carry out wider preaching and serve the congregation. The in stallation of the Telkom Indihomenetwork was carried out at the end of December 2018 and also proxy settings and the creation of a youtube channel, namely "manarul_huda official" completed in early January 2019. After the internetnetwork and hotspot were built, congregations could use free internet access at the mo sque and from routine religious studies could do live streaming or upload videos about da'wah activities at the mosque so that it can be accessed by fellow Muslims even though they don't come to the mosque. Hopefully, this program can provide benefits for the congregation and Takmir of Masjid Jami' Ma narul Huda Malang City.
\end{abstract}

Keywords: Internet and proxy network settings, youtube channel "manarul_huda official", STIMATA.

\begin{abstract}
Abstrak. Teknologi informasi merupakan sa lah satu a lat bantu dalam berbagai bidang tid ak terk ec uali dala m bidang da kwah Islam. Dakwah Islam dengan teknologi informa si y ang beru pa pen gajian live streaming ke youtube (dakwah online) sekarang ini la gi viral. Dakwa honlineini merupa kan k ein ginan daritakmir danjama'ah Masjid Jami' Manarul Huda. Setting jaringan internet dengan mikrotik dan pembuatan channel di youtube di Ma sjid Jami' Manarul Huda ini merupakan pemberdayaan masyarakat yaitu program penerapan iptek pada masyarakat di Masjid Jami' Manarul Huda. Program ini sebagai bentuk pengabdian masyarakat dari STMIK PPKIA Pra dnya Pa ramit a (STIMATA) Malang. Tujuan Pengabdian masyarakat ini a dalah untuk mengaplikasikan keilmuan yang a da pada kampus ke masyarkat lua s kususnya Masjid Jami' Ma narul Huda, supaya bisa melakukan dakwahnya lebih luas la gi dan melayanijama'ah. Pemasangan jaringan Telkom Indihome dilakukan pada akhir Desember 2018 dan juga settting mikrotik serta pembuatan channelyoutube yaitu "manarul_huda official" selesai a wal Januari 2019. Setelah terbangun ja ringan internet dan hotspotnya, maka jamaah bisa menggunakan akses internet gra tis di masjid dan dari kajian rutin keagamaan bisa melakukan live streaming a tau upload video tentang aktifitas dakwah dimasjid supaya bisa diakses oleh sesama muslim wa laupun tidak datang ke masjid. Mudah-mudahan program ini bisa memberikan manfaatbagijama'ah dan takmir Ma sjid Jami' ManarulHuda Kota malang.
\end{abstract}

Kata Kunci: Setting jaringan internet dan mikrotik, channel youtube "manar ul_huda official", STIMATA.

\section{PENDAHULUAN}

Sekitar tahun 2000 sampai sekarang (2020) masih tergolong era milenial, dimana masyarakat mengunakan internet untuk mengakses streaming meningkat tiga kali lipat (Kominfo, 2020). Isu-isu yang sering muncul dalam bentuk video atau tulisan bisa lewat facebook, instagram, twitter, youtube dengan streaming videonya dan juga yang tak kalah viralnya sekarang webinar dengan aplikasi online seperti zoom atau google meet dan juga yang lain. Model teknologi informasi ini banyak digunakan dalam banyak hal, seperti infotainment, market place, pendidikan dan juga dakwah secara online. Dakwak secara online ini sering diteliti untuk mengetahui efektifitasnya diantaranya oleh Zaini, “ Dakwah melalui intenet”, dengan hasil penelitian 
internet sebagai media masa dinilai sangat efektif dan potensial sebagai media komunikasi dakwah dengan berbagai kelebihan dan kekurangannya (Zaini, A., 2013). "Dakwah di internet: konsep ideal, kondisi objektif dan prospeknya", merupakan judul penelitian dari Yoga S.S, dengan hasil penelitian, internet dengan kondisi objektifnya sebagai salah satu media yang tengah digandrungi dunia. Internet menyangkut prospek dan kemungkinankemungkinannya menjadi media penyebar luasan ajaran Islam (Yoga S.S, 2015). Sulaeman dkk., meneliti tentang "Strategi Pemanfaatan Youtube dalam Bidang Dakwah Oleh Ulama Aceh", menghasilkan kesimpulan bahwa pemanfaatan youtube dalam bidang dakwah harus dilakukan supaya konten dari video youtube tidak hanya berisi hal-hal yang negatif, tetapi juga harus berisi hal-hal yang positif seperti video live streaming dakwah Islam (Sulaeman dkk.,2020). Dalam kenyataan yang ada di kota Malang tentang dakwah online dengan live streaming youtube dilakukan oleh beberapa masjid diantaranya channel youtube Masjid Agung J ami Malang(2020), Masjid Sabilillah Kota Malang(2020), Official account Al-Hikam Malang(2020).

Masjid Manarul Huda merupakan Masjid Jami' yang ada dikawasan RW. 01 di Kelurahan Sumbersari Kecamatan Lowokwaru kota Malang. Di masjid ini ada pengajian rutin tiap hari Ahad(Minggu), Selasa dan Rabu setelah sholat Magrib. Pengajian ini dilakukan secara konvensional yaitu disampaikan kepada jamaah yang hadir di masjid saja. Seiring dengan perkembangan teknologi dan keinginan Masjid Manarul Huda untuk meniru kegiatan dimasjid yang menggunakan fasilitas internet secara online (streaming youtube), dirasakan banyak memberikan manfaat dibanding pengajian secara konvensional (offline). Pengajian secara online bisa diikuti oleh jamaah baik yang ada di dalam masjid dan diluar masjid, selain itu bagi jamaah yang tidak sempat hadir bisa memutar ulang pengajian tersebut pada channel youtube yang dipakai. Dari permasalah atau keinginan masjid Manarul Huda adalah mengadakan pengajian secra online tersebut. Penulis selaku jamaah pada masjid Manarul Huda merasa terpanggil untuk melakukan pengabdian masyarakat yaitu program penerapan iptek pada masyarakat (Direktorat Riset dan Pengabdian Masyarakat RISTEKBRIN,2020). Program ini merupakan pemberdayaan masyarakat, dimana pihak kampus menugaskan dosen yang ahli dibidangnya akan melakukan setting jaringan dengan mikrotik untuk sarana live streaming pengajian pada channel youtube dan membuatkan jaringan mikrotik untuk para jama'ah. Selain hal tersebut juga mengajari marbot masjid dan remaja masjid yang akan menjadi operator live streaming dan operator voucher mikrotiknya, setelah setting jaringan ini selesai.

Setting jaringan internet dengan mikrotik di masjid Manarul Huda ini, digunakan mikrotik model RB951Ui-2HnD Giga Byte. Kemampuan mikrotik jenis ini berdasarkan info produknya dapat mengakses rata-rata pada level 5 sekitar 500 user(Mikrotik.id, 2020). Secara umum sistem manajemen bandwith pada mikrotik dapat digambarkan pada Gambar 1 dan Topologi jaringan yang digunakan pada Gambar 2 (Seting Rt/Rw Hotspot Rb951ui-2hnd, 2020).

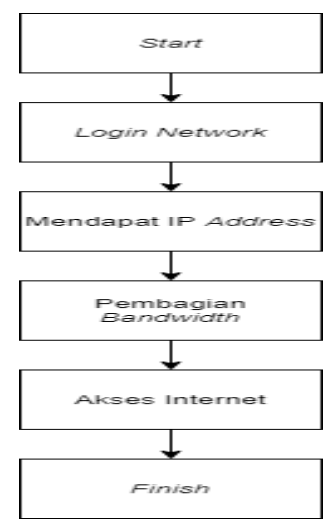

Gambar 1. Sistem manajemen bandwith

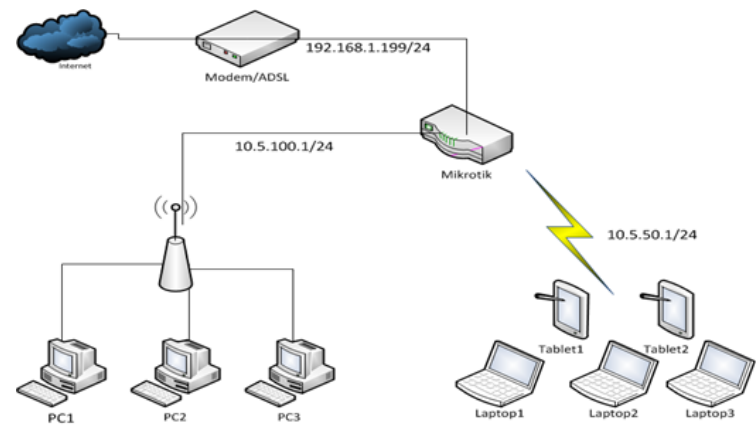

Gambar 2. Topologi jaringan yang digunakan 
Setting ini menggunakan metode queues tree. Queues tree merupakan salah satu sistem limitasi berikutnya yang sering diaplikasikan pada router untuk membatasi data rate. Queues tree memiliki sistem yang lebih kompleks dibandingkan Simple Queues. Queues tree membutuhkan "kerjasama" dari mangle untuk menandai paket-paket dari alamat IP atau subnet tertentu untuk dijadikan parameter limitasi. Dari hal tersebut diatas maka, queues tree merupakan manajemen bandwidth dengan mengalokasikan bandwidth secara maksimal, sehingga walaupun di client full ping time-nya pun masih stabil dan pembatasan trafik download dan upload dapat diatur pada firewall mangle. Sebelum melakukan konfigurasi pada metode queues tree, harus mengkonfigurasi mangle terlebih dahulu, fungsinya untuk menandai koneksi dan paket yang masuk pada server mikrotik. Langkah berikutnya setelah konfigurasi mangle adalah mengkonfigurasi queues tree. Setelah selesai setting, maka jaringan siap digunakan (Syaifuddin A. dkk.,2013).

\section{METODE PELAKSANAAN}

Metode pelaksanaan pemberdayaan masyarakat yaitu program penerapan iptek pada masyarakat di Masjid Manarul Huda ini dilaksanakan melalui tahapan atau diagram alur berikut :

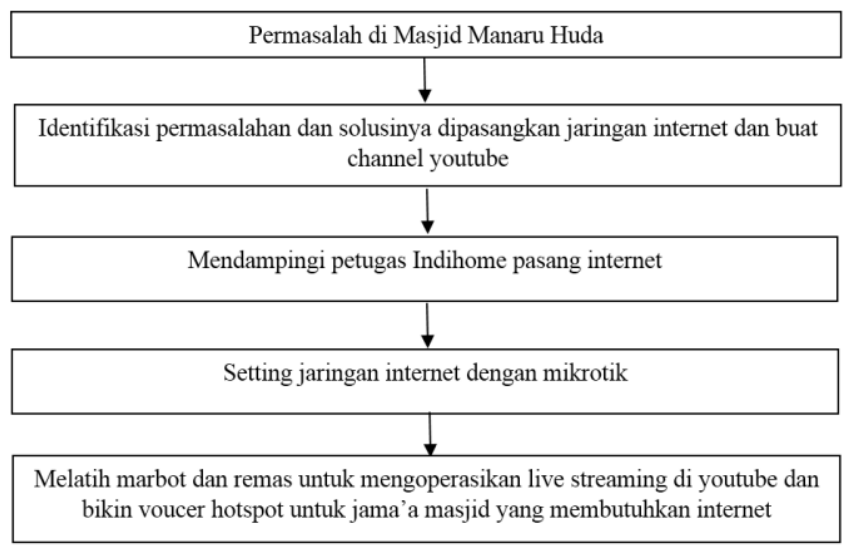

Gambar 3. Digram alur pengabdian masyarakat di Masjid Manarul Huda

Tahapan atau alur pada gambar 3 diatas dapat dijelaskan sebagai berikut :

\section{Permasalah di Masjid Manaru Huda}

Keinginan untuk melaksanakan pengajian di Masjid Manarul Huda secara online supaya bisa diikuti oleh jama'ah yang ada di dalam masjid dan diluar masjid serta bisa diputar ulang oleh jama'ah atau kaum muslimin yang lain, menjadikan keinginan ini untuk bisa diselesaikan. Penulis sebagai jama'ah di masjid ini mempunyai pemikiran untuk membantu hal tersebut seperti masjidmasjid yang lain melakukan pengajian secara online dengan streaming live di youtube.

2. Identifikasi permasalahan dan solusinya dipasangkan jaringan internet dan buat channel youtube

Dari point 1 diatas, dilakukan identifikasi masalah dan diputuskan untuk menerapkan iptek pada masyarakat dengan melakukan setting jaringan mikrotik untuk koneksi internet para jama'ah dan pembuatan channel youtube untuk pengajian online.

3. Mendampingi petugas Indihome pasang internet

Setelah disetujui untuk dilakukan pemasangan jaringan internet indihome oleh takmir dan yayasan Manarul Huda, penulis membantu mendaftarkan proses pemasangan indihome ke kantor Telkom Malang. Internet Indihome disabungkan oleh petugas Telkom pertengahan Desember 2018. Pemasangan jaringan indihome oleh petugas telkom didampingi oleh takmir masjid Manarul Huda serta pengabdi untuk mengatur tata letak yang diinginkan oleh takmir. Internet indihome ini medapatkan fasilitas internet dan modem / ADSL yang juga berfungsi sebagai akses point (AP) untuk wifi. Untuk sementara 
internet bisa digunakan oleh para jama'ah dengan wifi, karena belum terpasang mikrotik hotspot. Biaya pemasangan indihome dan tagihan bulanan dibayarkan oleh takmir masjid Manarul Huda dari jariyah para jama'ah. Foto petugas indihome sedang memasang jaringan internet didampingi oleh takmir masjid Manarul Huda seperti gambar 4 berikut :

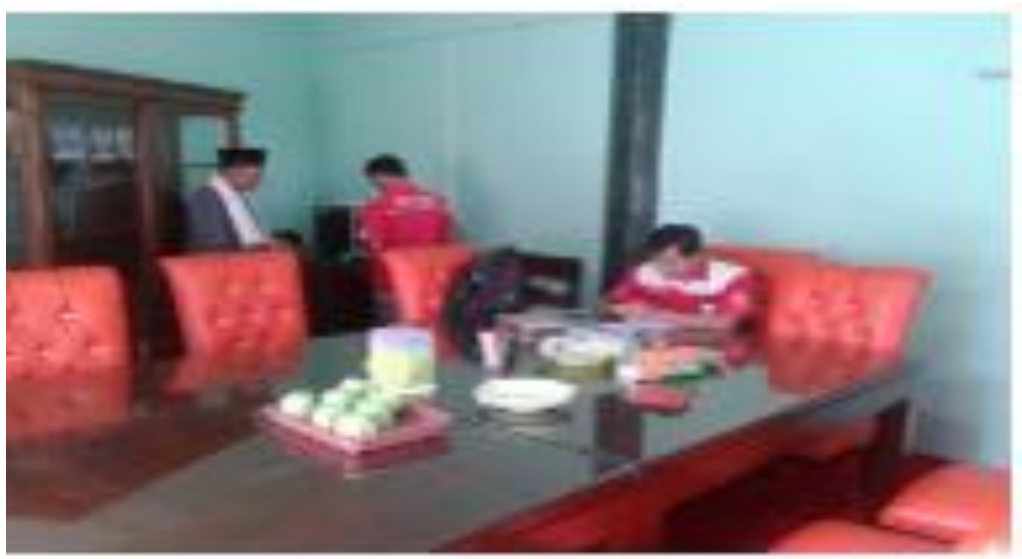

Gambar 4. Takmir mendampingi petugas indihome setting internet

4. Setting jaringan internet dengan mikrotik

Setelah internet indihome terpasang, selanjutnya dilakukan setting mikrotik untuk hotspot. Pemasangan mikrotik ini bertujuan untuk membagi bandwith kepada para jamaah supaya sama rata dalam akses internet dan juga ketika sedang live streaming di youtube bandwithnya banyak dipakai live streaming. Mikrotik yang digunakan yaitu mikrotik model RB951Ui-2HnD Giga Byte (gambar 5.) yang dibelikan oleh takmir masjid. Selain mikrotik ditambah satu akses point (AP) model TP-Link TL-wa901nd 300 Mbps (gambar 5.) yang dibelikan oleh pengabdi.
Akses point ini di tempatkan di TPQ Manarul Huda guna mendukung proses belajar mengajar di TPQ. Untuk kabel internet digunakan kabel LAN RJ-45 dan bahan lain yang digunakan dibelikan oleh pengabdi. Pada setting jaringan mikrotik ini menggunakan topologi jaringan seperti gambar 2 diatas dan metode queus tree. Diagram alur untuk setting queus tree seperti gambar 6. Setelah semua sudah jelas tentang topologi jaringan dan bahan yang mau di setting, berikutnya pengabdi mulai melakukan setting jaringan seperti pada gambar 7 .
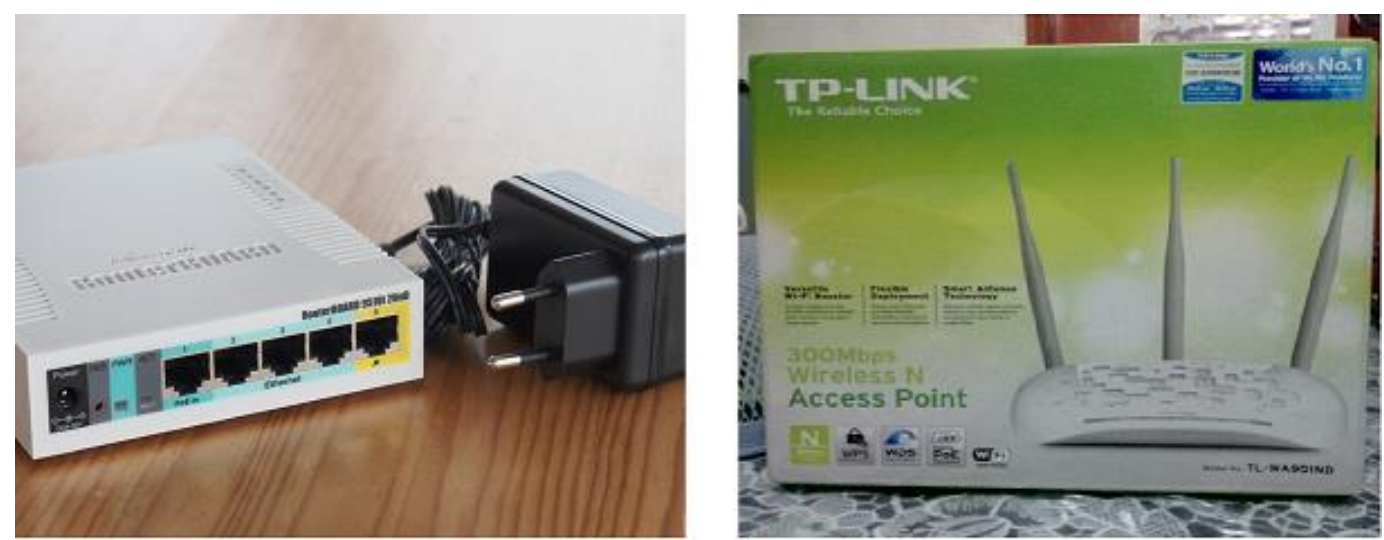

Gambar 5. Mikrotik model RB951Ui-2HnD Giga Byte dan TP-Link TL-wa901nd 300 Mbps 


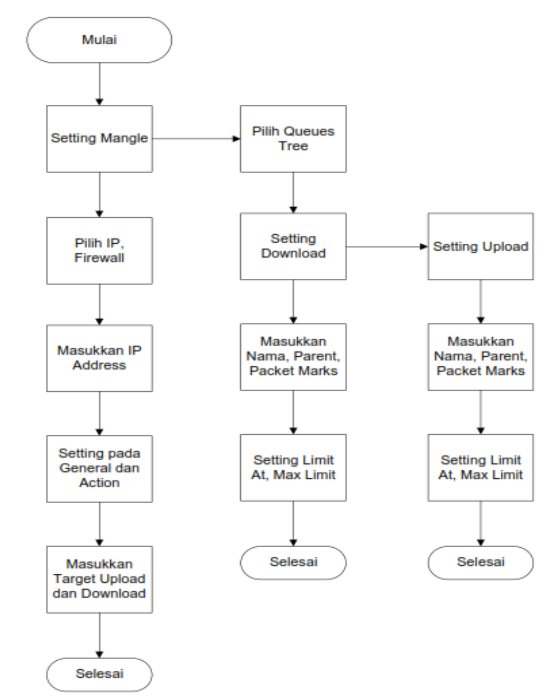

Gambar 6. Digram alur setting mikrotik model queus tree

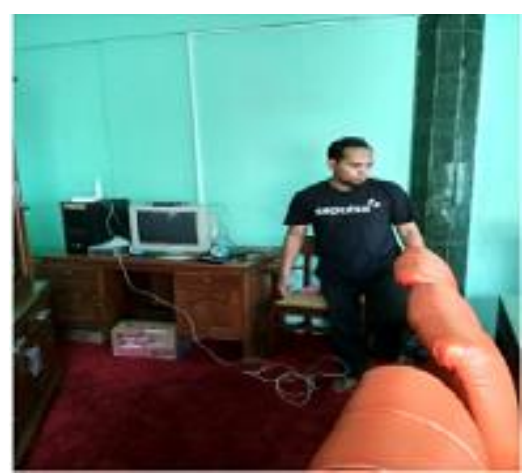

Gambar 7. Pengabdi mempersiapkan pemasangan mikrotik

5. Melatih marbot dan remas untuk melakukan pembelajaran operator mikrotik mengoperasikan live streaming di youtube dan bikin voucer hotspot untuk jama'a masjid yang membutuhkan internet.

Setting mikrotik sudah selesai dan sudah dipasang pada tempat yang ditentukan sekitar bulan Januari 2019. Selanjutnya pengabdi untuk membuat voucer hotspot yang diberikan jama'ah secara gratis. Berikut tampilan layar mikrotik untuk login dan user yang lagi aktif seperti gambar 8 berikut :
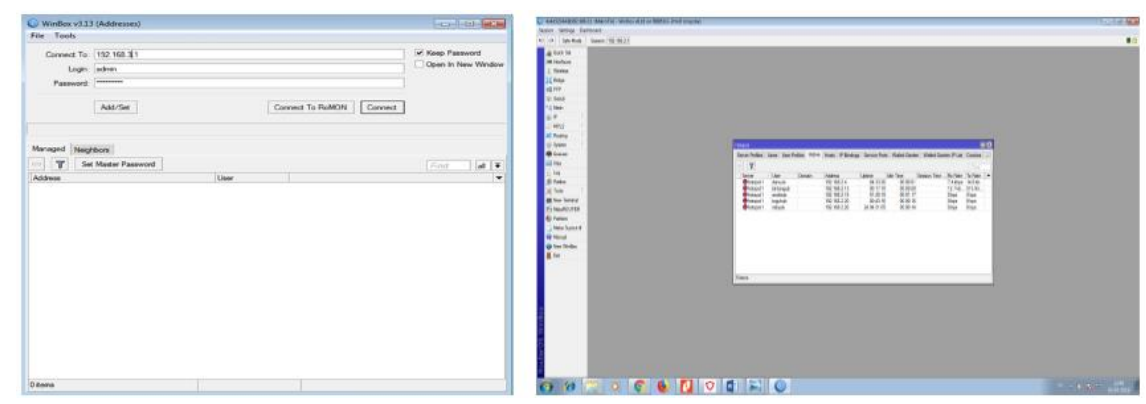

Gambar 8. Login ke mikrotik dan user yang lagi aktif hotspot

Video pengajian dishooting secara terpisah dilakukan upload secara manual oleh pengabdi di rumah, hal ini dilakukan karena belum tersedia komputer untuk melakukan live streaming ke youtube. Pengadaan komputer untuk live streaming ke youtube dilakukan oleh pengabdi 
dengan memberikan seperangkat komputer dan kabel koneksi ke handycam. Untuk kamera menggunakan handycame yang dipunyai oleh masjid Manarul Huda. Untuk melakukan shooting live streaming di youtube pertama kali dilakukan pada hari Selasa tanggal 12 Maret 2019. Sambil melakukan shooting live streaming ke youtube waktu pengajian, pengabdi mengajari sekaligus mempraktekan kepada operator yaitu marbot dan remas yang ditugasi. Pembelajaran ini dilakukan tiga kali dan dirasa cukup untuk operator yang bertugas. Untuk selanjutnya tanggung jawab ini diserahkan kepada operator.

\section{HASIL DAN PEMBAHASAN}

Pelaksanaan pemasangan jaringan internet dan setting mikrotik di masjid manarul huda berjalan dengan baik dan lancar. Hasil kegitan ini adalah terpasangnya infra struktur jaringan internet dengan mikrotiknya serta terbangunnya channel youtube yang dapat digunakan syiar agama berupa live streaming setiap ada kegiatan di masjid yang disiarkan langsung. Dengan demikian jamaah bisa akses internet secara gratis dan bisa mengikuti pengajian rutin secara offline datang langsung ke masjid ataupun bisa mengikuti secara online dari manapun berada. Dengan demikian permasalahan yang ada bisa teratasi sesuai dengan tahapan atau alur pelaksanaan pengabdian masyarkat berupa penerapan iptek pada masyarakat. Selanjutnya akan dibahas pelaksanaan pengabdian dan tingkat kepuasan atau penerimaan dari mitra pengabdian masyarakat ini yaitu pihak Masjid Manarul Huda.

\section{Pelaksanaa pengabdian}

Untuk tahap pertama pengabdi menampung permasalahan dari mitra pengabdi dan berusaha mencarikan solusinya dengan cara pengabdian masyarakat ini. Untuk tahapan kedua dengan kesepakatan antara takmir, jama'ah dan pengabdi sepakat dipasangkan jaringan internet dan channel youtube. Tahap yang ketiga yaitu mendampingi pemasangan jaringan internet dari indihome untuk ditempatkan kabel jaringan, modem dan wifinya bisa berjalan dan sesuai keinginan takmir. Tahap selanjutnya yaitu tahap ke empat adalah melakukan setting jaringan dengan menggunakan mikrotik. Mikrotik yang digunakan adalah model RB951Ui-2HnD Giga Byte ditambah dengan akses point (AP) merk TPLink TL-wa901nd 300 Mbps. Untuk setting mikrotiknya menggunakan metode queus tree dengan mengikuti diagram alur seperti gambar 6 diatas. Tahapan settingnya dapat dilihat sebagai berikut :

a. Tahap awal dalam setting ini adalah mengkonfigurasi mangle seperti gambar 9 berikut :
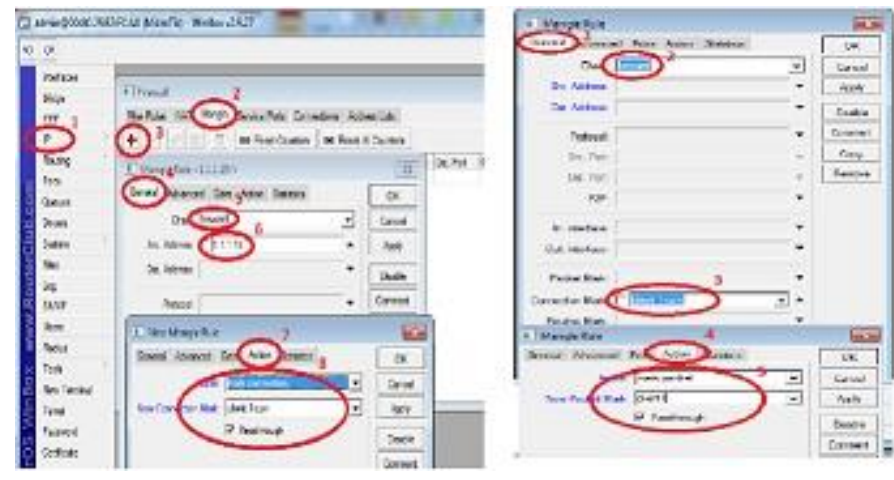

Gambar 9. Form menu setting mangle

Setelah dilakukan setting mangle awal dihasilkan akhir setting mangle gambar 10 berikut :

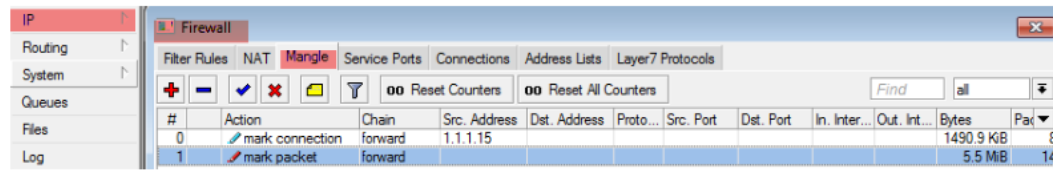

Gambar 10. Hasil akhir setting mangle 
b. Selanjutnya dilakukan setting queus tree seperti gambar 11 berikut :
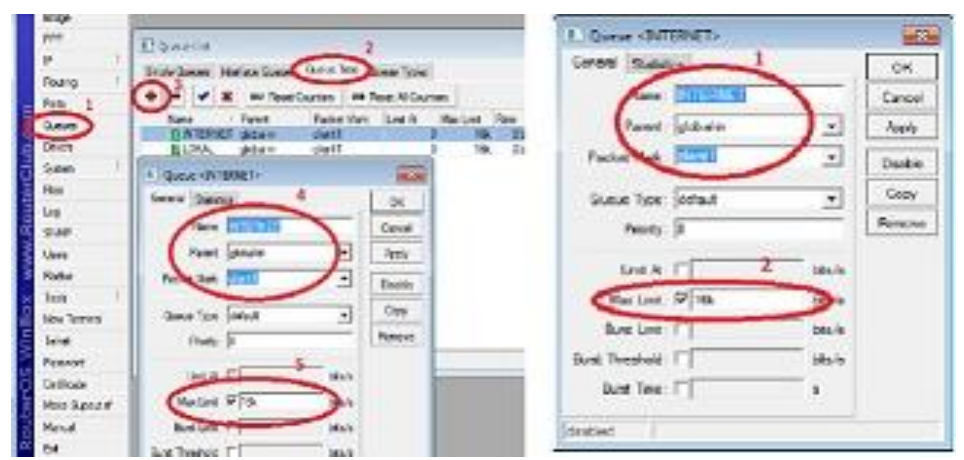

Gambar 11. Setting queus tree
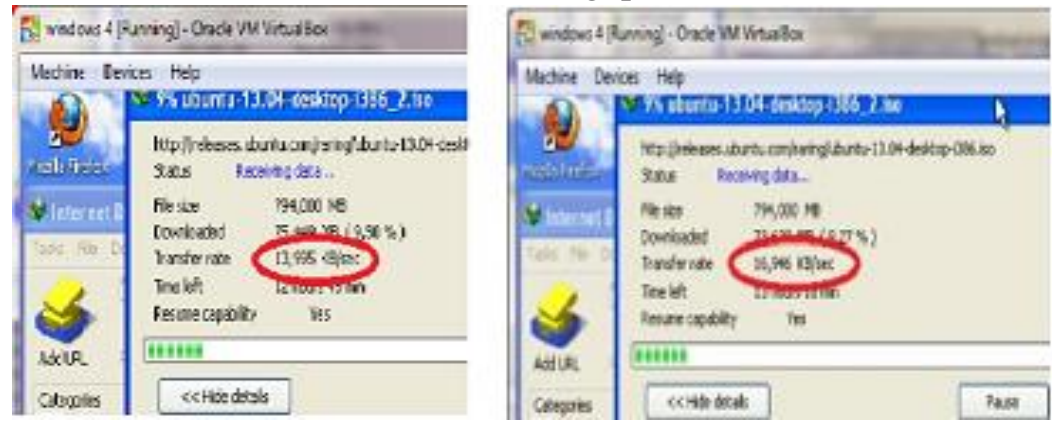

Gambar 12. Kecepatan download dan upload test untuk model queus tree

Setelah setting queus tree selesai dilakukan dan ditest sebelum ditempatkan di area hotspot, hasilnya test untuk download dan upload seperti gambar 12 sebagai berikut :

Tampak pada gambar 12, test terhadap download dan upload berjalan sukses. Ini berarti install mikrotiknya sudah sukses dan tinggal di pasang di tempat yang telah ditentukan.

c. Tahap selanjutnya yaitu mengajari operator (marbot dan remas yang ditunjuk)

Pada tahap ini pengabdi melatih operator untuk mengoperasikan winbox versi 3.2.5 untuk 32 bit. Cara membuka winbox seperti gambar 8 diatas dan cara bikin voucer baru, mendelete user atau melihat user yang aktif hotspot juga pada gambar 8 .

Setelah setting jaringan mikrotik dan pembelajarannya selesai, kegiatan selanjutnya adalah pembelajaran shooting live streaming ke youtube. Sebelum bisa live streaming shooting video dilakukan manual kemudian di edit dan diupload ke channel youtube "manarul_huda official". Ini dilakukan secara manual karena belum tersedianya komputer yang bisa dipakai untuk live streamingnya. Pengabdi berusaha untuk pengadaan komputer supaya bisa live streaming ke youtube supaya mengurangi pekerjaan edit dan upload ke youtube. Komputer yang digunakan yaitu PC komputer dengan prosesor pentium core 2 duo dengan RAM 2 GB serta menggunakan sistem operasi windows 7. Untuk software live video streaming yaitu vmix versi 17 . Setting vmix ke komputer dilakukan oleh pengabdi dan setelah di instal di lakukan tutorial shooting video live streaming ke youtube kepada operator. Selanjutnya operator setelah bisa mengoperasikan di berikan tanggung jawab untuk shooting live streaming dan merawatnya.

2. Tingkat kepuasan mitra pengabdian

Untuk mengetahui apakah pengabdian ini memberikan hasil yang positif atau bisa memberikan kepuasan atau manfaat bagi mitra pengabdian dapat dilihat dari hal-hal berikut :

a. Ucapan terima kasih mitra pengabdian kepada pengabdi

Ucapan terima kasih ini dilakukan secara lisan dari takmir dan jama'ah kepada pengabdi.

b. Melihat channel "manarul_huda official"

Dari channel dapat dilihat pada saat draf jurnal ini ditulis yaitu sekitar bulan Februari 
2020 terdapat subcriber sebanyak 128 subcriber dan 109 video yang bisa terupload. Selain itu dari 109 video tersebut sudah ditonton sebanyak 6751 viewer. Selain pengajian rutin hari Ahad, Selasa dan Jum'at yang di shooting, terdapat juga video yang dilakukan shooting live streaming berupa santunan anak yatim dan dhuafa, takbir keliling Idhul Adhka, sholawatan tahun baru, banjari, penyerahan wakaf rumah dan tanah jamaa'ah ke Yayasan Manarul Huda dan beberpa video dengan topik yang lain. Ini berarti bahwa takmir masjid dan jama'ah dengan senang hati mempergunakan internet dan channel video ini untuk acara-acara yang bermanfaat. Untuk mengetahui lebih jauh tentang channel ini bisa dilihat di youtube dengan mengetikkan "manarul_huda official" atau dari browse diketikkan "youtube.com/channel/UCp-gzrWsgvplUUGfocD49w".

Untuk meningkatkan fungsi dari channel youtube "manarul_huda official", para jamaah dan takmir masjid mengajak ke pemirsa channel ini untuk selalu mensubcribe demi semarak dakwah masjid ini.

\section{SIMPULAN DAN SARAN}

Setting jaringan mikrotik dan pembuatan channel youtube untuk masjid Jami' Manarul Huda Sumbersari kota Malang bisa berjalan dengan baik dan lancar, hal ini menjadikan kedua belah pihak yaitu tim pengabdi dan pihak masjid senang sehingga sampai sekarang live streaming pengajian rutin masih tetap berjalan dan jamaah dapat akses internet gratis dari masjid. Selain hal tersebut, channel ini bisa digunakan juga untuk live streaming acara lain yang berhubungan dengan kegiatan keagamaan, sosial pendidikan atau kemasyarakatan.

Saran yang bisa disampaikan oleh tim pengabdi ketika setting infrastruktur tersebut dan bikin channel youtube yaitu pemeliharaan jaringan internet dan peningkatan tim operasional live streaming untuk bisa meningkatkan jumlah dan kwalitas siaran dakwah dengan memberdayakan remaja masjid, karena di kaum remajalah dakwah ini bisa berkembang.

\section{DAFTAR PUSTAKA}

Direktorat Riset dan Pengabdian Masyarakat RISTEK-BRIN, (2020), Panduan Penelitian dan Pengabdian Kepada Masyarakat, Edisi XIII.

Kominfo (2020), mengenal generasi milenial, <https://www.kominfo.go.id/content/detail /8566/mengenal-generasi-

illennial/0/sorotan_media $>$ (diakses, 16 Desember 2020).

Masjid Agung jami' Malang, $<$ https://www.youtube.com/channel/UCQk 7gDrPWcVrI7GuPdQbTAA> (diakses, 16 Desember 2020)

Masjid Sabilillah Kota Malang, $<$ https://www.youtube.com/channel/UCA5 1AmL8ldy5qi-t5q4nYQw> (diakses, 16 Desember 2020)

Mikrotik.id, $<$ http://www.mikrotik.co.id/artikel_lihat.ph p?id=7> (diakses, 16 Desember 2020)

Official account Al-Hikam Malang, $<$ https://www.youtube.com/channel/UC8n5cm7fDimw_DEbh3aVTA> (diakses, 16 Desember 2020)

Seting Rt/Rw Hotspot Rb951ui-2hnd, <http://www.forummikrotik.com/hotspotdude-user-manager/31622-seting-rt-rwhotspot-rb951ui-2hnd.html> (diakses, 16 Desember 2020)

Sulaeman A.R., Fazri, A. dan Fairus. (2020), Strategi Pemanfaatan Youtube Dalam Bidang Dakwah Oleh Ulama Aceh, Jurnal Communication, Vol. 11 No.1. 81 - 92.

Syaifuddin A. Yunus M. \& Sundari R., (2013). Perbandingan metode Simple Queues dan Queues Tree untuk optimasi manajemen bandwidth jaringan komputer di STMIK PPKIA Pradnya Paramita Malang. Jurnal Teknologi Informasi Vol. 4 No. 2. P.60-74.

Yoga, S.S, (2015), Dakwah di internet: Konsep Ideal, Kondisi Objektif dan Prospeknya, Jurnal Al-Bayan / Vol. 22, Nn. 31. P. 5670.

Zaini, A. (2013), Dakwah Melalui Internet. ATTABSYIR, Jurnal Komunikasi Penyiaran Islam. Vol. 1. No. 1 p.93-108. 